\title{
Using Technology in ESL Classroom: Highlights and Challenges
}

\author{
Fetylyana Nor Pazilah, Harwati Hashim*, Melor Md. Yunus \\ Faculty of Education, Universiti Kebangsaan Malaysia, Selangor, Malaysia \\ Email: ^harwati@ukm.edu.my
}

How to cite this paper: Pazilah, F. N., Hashim, H., \& Yunus, M. Md. (2019). Using Technology in ESL Classroom: Highlights and Challenges. Creative Education, 10, 3205-3212.

https://doi.org/10.4236/ce.2019.1012244

Received: October 16, 2019

Accepted: November 27, 2019

Published: November 30, 2019

Copyright $\odot 2019$ by author(s) and Scientific Research Publishing Inc. This work is licensed under the Creative Commons Attribution International License (CC BY 4.0).

http://creativecommons.org/licenses/by/4.0/ (c) (i) Open Access

\begin{abstract}
Technology is evolving rapidly in the past two decades. Many are familiar with technology and gradually becoming digital natives. In this technological era, the application of technology has eased our ways in various fields of work particularly in the education field. Technology has also proven its effectiveness in language teaching which includes as a source of motivation and provides room for authentic learning. However, there are still disadvantages in using technology to teach. Students may get easily distracted and might misuse the technology. Other than that, frequent use of technology can limit students thinking potential. Hence, this paper reviews the highlights and challenges of using technology in language teaching. This paper could be a source of reference by teachers who are planning to integrate technology in ESL classroom. Future research can look into how technology affects students' attitude.
\end{abstract}

\section{Keywords}

Technology, ESL Classroom, Motivation, Authentic Learning, Distraction, Thinking Potential

\section{Introduction}

Technology is no longer foreign to the earth's citizens. Technology has played its role in multiple fields of work, particularly in education. During the last two decades, the implementation of Information and Communication Technology (ICT) in language education has become a real topic of interest (Ahmed \& Naser, 2015). The use of technology has become significant in the teaching and learning process in and out of class. Technology opens a window of improvement in language learning. Not only that, technology allows teachers to enhance classroom activities and language learning process (Ahmadi \& Reza, 2018; Ha- 
shim, 2018). This shows that there is a brand-new era which assigns challenging responsibilities for modern teachers. The traditional teaching method has been changed drastically with extraordinary access to technology. The implementation of technology has provided options for a more interesting and productive teaching and learning sessions predominantly in language learning. According to Shyamlee and Phil (2012), technology has provided significant drivers for both social and linguistic change.

With English as an international language and its development around the world, English is used as a second language in a country such as India and Malaysia. To some people, English acts as their first language. English has become the language for instruction and curriculum in many countries. As the number of English learners increases, new teaching methods have been implemented to test the effectiveness of the teaching process (Shyamlee \& Phil, 2012). Language is one of the most substantial elements in communication. Students utilize different parts of English language skills such as listening, speaking, reading, and writing for their proficiency and communication (Grabe \& Stoller, 2002). Research has found multiple shreds of evidences of the use of information and communication technology (ICT) on students (Cakici, 2016). However, there are also negatives pieces of evidences of the use of technology.

Rosicka and Mayerova (2014) stated that the purpose of the new era of education is to make the current and upcoming generation active participants in society with the implementation of technology. Harwati (2018) stated that the current generation is being called digital natives as they have a high level of computer literacy. It would be utterly unimaginable if the new ear of education does not implement technology as a medium of communication and exchanging ideas (Ahmed \& Naser, 2015). Using computers as learning tools can promote efficient learning when learners are engaged in knowledge construction, collaboration, and reflection (Rosicka \& Mayerova, 2014). For the young technology-driven generation, the application of technology in teaching and learning sessions can bring more interest and motivation to learn. Hence, this paper reviews the highlights and challenges of implementing technology in an ESL classroom.

\section{Technology in ESL Classroom}

The use of ICT in the education field has been increasing (Rafiq \& Hashim, 2018). Educational technologies promised to change the way teachers teach and students learn forever (Abunowara, 2016). The white canvas of language teaching and learning has experienced major creativity and changes over the decade with the emerging of a new era of education and technology. Technology has transformed the field of education, lower and higher education, which has a great impact on the field of English as a Second Language (ESL) teaching (Mansor \& Rahim, 2017). As time changed, teachings changed too. In Malaysia, the changes begin in the classroom where technologies are being implemented such as projectors, laptops, and wireless internet (Yunus, 2018). 
The technology implementation is defined as "the process of determining which electronic tools and which methods from implementing them are the most appropriate responses to give classroom situations and problems" (Roblyer \& Doering, 2010, p. 8). Computer-assisted language learning (CALL) has become normalized in the educational process (Bax, 2012). The key to a successful use of technology in teaching and learning session not only lies in hardware or software but also in our human ability as teachers have to plan, design and implement effective educational activities (Abunowara, 2016).

Educational multimedia is currently being used commonly in teaching and learning of English language (Yunus, Hashim, Embi, \& Lubis, 2010). Another commonly used element in the digital era as part of technology would be social media. Social media augments the learning experience by allowing the learners and teachers to connect and interact in a more innovative and interesting way (Khan, 2015). Social media such as Facebook, Blog, Instagram, e-mail and Twitter provide a platform where users can interact and exchange ideas as well as to find answers through collaboration and discussion (Mansor, 2016).

With the help of technology, students' view on learning has shifted (Daniels \& Pethel, 2005). New and more advanced technologies are not only transforming the way the students' view learning but also transforming the way "educators think about education and literacy" (Pilgrim, Bledsoe, \& Riley, 2012: p. 30). "These tools are also continuing to grow and transform literacy instruction" and they also helping students to "internalize lifelong skills needed for success in this global society" (Saine, 2012: p. 45) Technology will not substitute great teachers but technology in the hands of great teachers can be transformational (Roy, 2019).

\section{Highlights}

\subsection{Source of Motivation and Interest}

With the constant advancement of technology, many ESL teachers have adopted a more fun and interesting teaching techniques to ensure exciting lessons (Morat, Shaari, \& Abidin, 2016). Motivation is the key and has been known as one of the factors that influence success in second language learning. According to $\mathrm{Ng}$ and $\mathrm{Ng}$ (2015), motivation is known as s stimulant to achieve a specific target. Intrinsic and extrinsic motivation is the two types of motivation. Intrinsic motivation can be found within the individual and related to the sense of well-being whereas extrinsic motivation comes from outside the individual $(\mathrm{Ng} \& \mathrm{Ng}$, 2015).

Porter (1991, as cited in Morat, Shaari, \& Abidin, 2016) stated that the three important aspects related to motivation which are what energizes human behavior, what directs or channels such behavior, and how this behavior is maintained or sustained. Nowadays, teachers are using technology to enrich and enhance the comprehension of the course content (Hicks, Reid, \& George, 2001). Implementing multiple types of technology equipment provides ESL learners a sense of 
freedom, motivation, and encouragement they need for the learning process (Roy, 2019). Technology equipment such as videos provide the ability to present in both audio and visual (Canning-Wilson \& Wallace, 2000) is probably the reason why it is so popular as it can to increase the learners' motivation in which they perceived the teaching and learning session as interesting (Harmer, 2001).

Based on a study by Morat, Shaari, and Abidin (2016), the implementation of technology showed sustainability in the students' motivation to learn. A study conducted by Blachowicz, Bates, Berne, Bridgman, Chaney, and Perney (2009) to observe the technology used by the students, to observe the dynamics and teacher-centered choices in technology use, to look at the student learning and to learn about student and teacher perceptions and beliefs on technology. The results showed that the students were motivated and attentive when working in their task.

\subsection{Authentic Learning}

Authentic learning is no longer new in the era of digital education. Suggestively, educational researchers have concluded that the value of authentic teaching and learning activity is no longer constrained to learning in real-life locations and practice, but what benefits from authentic activity can be realized through design of Web-based learning environments (Lombardi, 2007). Software visualizations, images, audio, and haptic bring thoughts to life (Lombardi, 2007). Many researchers have also revealed several important characteristics which added to the evolving and advancing authentic learning. Authentic learning is based on real-life and provides an authentic experience (Herrington \& Kevin, 2007).

At the same time, many teachers have endeavored to use technology such as computers and videos to design an authentic learning experience for the students (Herrington, Reeves, \& Oliver, 2007). As the number of English learners is increasing, many different teaching methods have been implemented to assess the effectiveness of the teaching process. The use of authentic materials in form of films, radio, TV has been in the education field for quite some time and these technologies have proved to be successful in language teaching and learning and replacing the traditional method (Shyamlee \& Phil, 2012).

Multimedia teaching improves teaching content and makes the best of class time and halt the "teacher-centered" teaching pattern and expand class productivity. According to Shyamlee and Phil (2012), the utilization of technology and multimedia creates a more vivid, visual and authentic environment for English learning, stimulates students' initiatives and economizes class time and increase class information Jayanthi and Kumar (2016) stated that the implementation of technology bring positive impacts on language learning. It provides materials availability, improves students' attitude, brings authenticity to the classroom and it is student-centered. The availability of authentic materials such as images, animation, audio, and video clips facilitate presenting and practicing a language (Cakici, 2016). 


\section{Challenges}

\subsection{Restrict Students' Thinking Potential}

It is obvious to say that technology has proven its effectiveness in language learning. However, along with other manmade teaching methods, it still has its flaws. Language learning may not require demonstrations through various steps but the tense and orderly atmosphere is formed through questions and answer between teachers and students (Shyamlee \& Phil, 2012). In the common traditional method of teaching, teachers would usually raise an impromptu question and guide the students on how to answer the questions. However, with the implementation of technology, students would rather find the answer online.

According to Yunus, Nordin, Salehi, Hun, and Embi (2013), the concept of ICT in education is that ICT enables information gathering, management, manipulation, access and communication in various forms. This shows that information is at the tip of our finger without having to think. It also disregards the emphasis and the importance of teaching. It disdains the students' thinking, inspiring their paths to think, and contemplating problems solving. Shyamlee and Phil (2012) continue by stating that students should be able to think innovatively and exploring questions and possible answers without having to have a know-it-all assistant. Multimedia should not be taking students' time for thinking.

According to Simin and Heidari (2013), the integration of technology can also limit other skills such as speaking communication. Technology may be a great medium for online interacting; however, it will decrease the speaking communication among students and teachers. The introduction of technology may include audio, visual, textual effect which fully meets the audio and visual requirements of the students and can increase their interest. However, it also results in poor communication among students and teachers (Shyamlee \& Phil, 2012).

\subsection{Possible Distraction and Misuse}

There are countless things people can use when they are online. Students particularly can get distracted with the entertaining side technology has to offer. Surfing the internet without parental supervision can be harmful and dangerous for the students who are minors. Students who are digital natives tend to spend their upmost time on social media. Social media such as Facebook and Instagram can distract students from doing what they are supposed to do. When online, students can get easily distracted with the entertainment technology what computers have to offer. Other than that, technology provides the easiness of online plagiarism.

Boudjadar (2015) claimed that technology allows room for information from around the world where students can copy and paste from the internet. Gerard (2012) stated that "although there is no evidence that web-derived plagiarism is any more widespread than other kinds, instructors are understandably con- 
cerned about the ease with which students can plagiarize, either intentionally or not" (Gerrard, 2012: p. 426). Claiming and copying other's work pretending that it is theirs can never improve their work (Boudjadar, 2015).

\section{Conclusion}

All in all, technology has proven its significance to the education field. With the integration of technology, students can be motivated and they become more indulge in learning. Technology provides a more interesting classroom environment and attracts students' attention. However, the implementation of technology in language learning has its disadvantages. Students may get distracted with the entertainment the technology has to offer. Other than that, they might misuse while using technology. Hence, the use of technology should be limited and students should be under supervision while using computers. This paper implies to all teachers who are planning to integrate technology in an ESL classroom. Future research can look into how technology affects students' attitude.

\section{Acknowledgements}

This research was supported by the grant from the Faculty of Education, Universiti Kebangsaan Malaysia KRA-2018-044 and PP-FPEND-2019.

\section{Conflicts of Interest}

The authors declare no conflicts of interest regarding the publication of this paper.

\section{References}

Abunowara, A. M. (2016). Using Technology in EFL/ESL Classroom. International Journal of Humanities and Cultural Studies, 1, 7-23.

Ahmadi, D., \& Reza, M. (2018). The Use of Technology in English Language Learning: A Literature Review. International Journal of Research in English Education, 3, 115-125. https://doi.org/10.29252/ijree.3.2.115

Ahmed, K., \& Nasser, O. (2015). Incorporating iPad Technology: Creating More Effective Language Classrooms. TESOL Journal, 6, 751-765. https://doi.org/10.1002/tesj.192

Bax, S. (2012). How Does Technology Become Fully Effective in Language Education? The Social and Psychological Dimensions of Educational Normalization. In Keynote Address of the Jaltcall 2012 Conference. Nishinomiya: Konan Cube, Konan University.

Blachowicz, C. L., Bates, A., Berne, J., Bridgman, T., Chaney, J., \& Perney, J. (2009). Technology and At-Risk Young Readers and Their Classrooms. Reading Psychology, 30, 387-411. https://doi.org/10.1080/02702710902733576

Boudjadar, T. (2015). ICT in the Writing Classroom: The Pros and the Cons. International Journal of Applied Linguistics and English Literature, 4, 8-13. https://doi.org/10.7575/aiac.ijalel.v.4n.1p.8

Cakici, D. (2016). The Use of ICT in Teaching English as a Foreign Language. Participatory Educational Research, 4, 73-77.

Canning-Wilson, C., \& Wallace, J. (2000). Practical Aspects of Using Video in the Foreign Language Classroom. The Internet TESL Journal, 6, 36. 
Gerrard, L. (2012). Writing in Multiple Media. In I. L. Clark (Ed.), Concepts in Composition: Theory and Practice in the Teaching of Writing (2nd ed.). New York: Routledge.

Grabe, W., \& Stoller, F. L. (2002). Teaching and Researching Reading. New York: Pearson Education. https://doi.org/10.4324/9781315833743

Harmer, J. (2001). The Practice of English Language Teaching (3rd ed.). Harlow: Longman.

Hashim, H. (2018). Application of Technology in the Digital Era Education. International Journal of Research in Counseling and Education, 2, 1-5. https://doi.org/10.24036/002za0002

Herrington, J., \& Kervin, L. (2007). Authentic Learning Supported by Technology: Ten Suggestions and Cases of Integration in Classrooms. Educational Media International, 44, 219-236. https://doi.org/10.1080/09523980701491666

Herrington, J., Reeves, T. C., \& Oliver, R. (2007). Immersive Learning Technologies: Realism and Online Authentic Learning. Journal of Computing in Higher Education, 19, 80-99. https://doi.org/10.1007/BF03033421

Hicks, M., Reid, I., \& George, R. (2001). Enhancing On-Line Teaching: Designing Responsive Learning Environments. International Journal for Academic Development, 6, 143-151. https://doi.org/10.1080/713769258

Jayanthi, N. S., \& Kumar, R. V. (2016). Use of ICT in English Language Teaching and Learning. Journal of English Language Teaching and Learning, 3, 34-38.

Khan, A. (2015). Using Films in the ESL Classroom to Improve Communication Skills of Non-Native Learners. ELT Voices, 5, 46-52.

Lombardi, M. M. (2007). Authentic Learning for the 21st Century: An Overview. EDUCAUSE Learning Initiative, 1, 1-12.

Mansor, N. (2016). Enhancing Communication via Social Media in ESL Classroom. In 6th International Conference on Language, Education, and Innovation.

Mansor, N., \& Rahim, N. A. (2017). Instagram in ESL Classroom. Man in India, 97, 107-114.

Morat, B. N., Shaari, A., \& Abidin, M. J. Z. (2016). Facilitating ESL Learning Using Youtube: Learners' Motivational Experiences (pp. 23, 137). Banda Aceh: Association of Malaysian Researchers and Social Services Faculty of Teacher Training and Education, Universitas Syiah Kuala, Darussalam.

Ng, C. F., \& Ng, P. K. (2015). A Review of Intrinsic and Extrinsic Motivations of ESL Learners. International Journal of Languages, Literature and Linguistics, 1, 98-105. https://doi.org/10.7763/IJLLL.2015.V1.20

Pilgrim, J., Bledsoe, C., \& Reily, S. (2012). New Technologies in the Classroom. Delta Kappa Gamma Bulletin, 78, 16-22.

Rafiq, M. K. R., \& Hashim, H. (2018). Augmented Reality Game (ARG), 21st Century Skills and ESL Classroom. Journal of Educational and Learning Studies, 1, 29-34. https://doi.org/10.32698/0232

Rosicka, Z., \& Hošková-Mayerova, Š. (2014). Motivation to Study and Work with Talented Students. Procedia-Social and Behavioral Sciences, 114, 234-238. https://doi.org/10.1016/j.sbspro.2013.12.691

Roy, A. (2019). Technology in Teaching and Learning. International Journal of Innovation Education and Research, 7, 414-422. https://doi.org/10.31686/ijier.Vol7.Iss4.1433

Saine, P. (2012). iPods, iPads, and the SMARTBoard: Transforming Literacy Instruction and Student Learning. New England Reading Association Journal, 47, 74. 
Shyamlee, S. D., \& Phil, M. (2012). Use of Technology in English Language Teaching and Learning: An Analysis. In International Conference on Language, Medias and Culture (Vol. 33, pp. 150-156).

Simin, S., \& Heidari, A. (2013). Computer-Based Assessment: Pros and Cons. Elixir International Journal, 55, 12732-12734.

Yunus, M. M. (2018). Innovation in Education and Language Learning in 21st Century. Journal of Sustainable Development Education and Research, 2, 33-34. https://doi.org/10.17509/jsder.v2i1.12355

Yunus, M. M., Hashim, H., Embi, M. A., \& Lubis, M. A. (2010). The Utilization of ICT in the Teaching and Learning of English: "Tell Me More". Procedia-Social and Behavioral Sciences, 9, 685-691. https://doi.org/10.1016/j.sbspro.2010.12.218

Yunus, M. M., Nordin, N., Salehi, H., Sun, C. H., \& Embi, M. A. (2013). Pros and Cons of Using IICT in Teaching ESL Reading and Writing. International Education Studies, 6, 119-130. https://doi.org/10.5539/ies.v6n7p119 